\title{
New record of Allamanda blanchetti Kunth (Apocynaceae) for the Brazilian Atlantic Forest
}

\author{
Diego Santos ${ }^{*} \bullet$, Swami Leitão Costa ${ }^{\circledR}$, Francisco Carlos Pinheiro da Costab® \\ a Programa de Pós-Graduação em Biodiversidade, Universidade Federal Rural de Pernambuco, \\ Recife, 52171-900, Pernambuco, Brasil.*fdsantosbot@gmail.com \\ b Universidade Federal de Campina Grande, Cajazeiras, 58900-000, Paraíba, Brasil.
}

Received: June, 26, 2021 / Accepted: August 7, 2021 / Published online: September 30, 2021

\begin{abstract}
This study report the first record of Allamanda blanchetii Kunth in the Atlantic Forest, Brazil. This species was collected from an upland forest in Semi-deciduous Seasonal Forest. This occurrence adds new information about the distribution of this species and expands its range to Brazil, which is important for its conservation. We provide taxonomic information, distribution maps, conservation status assessment, photograps, and an identification key for the Allamanda L. species in the Atlantic Forest.
\end{abstract}

Keywords: Conservation status, flora, geographic distribution, taxonomy.

\section{Novo registro de Allamanda blanchetti Kunth (Apocynaceae) para a Mata Atlântica brasileira}

\begin{abstract}
Resumo
Este estudo documenta o primeiro registro de Allamanda blanchetii Kunth para a Mata Atlântica, Brasil. Esta espécie foi coletada em Floresta Semidecídua Sazonal em brejos de altitudes. Esta ocorrência adiciona novas informações sobre a distribuição desta espécie e expande sua área de extensão que é importante para a sua conservação. Nós fornecemos informações taxonômicas, mapa de distribuição, avaliação do estatus de conservação, fotografias, e uma chave de identificação para as espécies de Allamanda L. para a Mata Atlântica.
\end{abstract}

Palavras-chave: Status de conservação, distribuição geográfica, flora, taxonomia.

The Brazilian Atlantic Forest is one of the 25 global priorities for biodiversity conservation (Tabarelli \& Santos, 2004), housing about 16,454 species of vascular plants, 7,829 of which are endemic (BFG, 2020). Its biodiversity is distributed in five centers of endemism throughout this phytogeographic domain. Of these centers, two are located north of the São Francisco River, covering the states of Alagoas, Pernambuco, Paraíba, Rio Grande do Norte, Ceará, and Piauí and one of these centers comprises the Brejosb de Altitudes, which are "islands" of semi-deciduous seasonal forest located in the semi-arid region of Ceará and Piauí (Tabarelli \& Santos, 2004).

In the Atlantic Forest, there are groups of endemic species whose degree of threat was not evaluated (CNCFlora, 2021). Among these groups, Allamanda L. stands out, comprising 14 species found in equatorial, tropical and subtropical ranges, especially along the eastern coast (Sakane, 1981). In Brazil, there are 13 species (11 endemic) distributed in all regions and in the Amazon, Caatinga, Cerrado and Atlantic Forest domains. From these domains, the Atlantic Forest and Cerrado stand out with the second highest species diversity for this genus (six species each) and in the Atlantic Forest from the Northeastern region, the genus is represented by four species distributed mainly in Bahia State (BFG, 2018).

This genus is charaterized by shrubby habits with verticillate leaves, an infundibuliform corolla, a nectariferous disk that is always present, a fruit capsule that usually comes with spines, and winged and oval seeds (Sakane \& Shepherd, 1986).

During a floristic survey carried out between 2013 and 2016 to increase knowledge about the flora of an upland forest in the Serra de Itacoatiara, Massif of Uruburetama, Ceará State, we collected Allamanda specimens that we confirmed as belonging to A. blanchetii Kunth after morphological analysis. After surveying the literature and analyzing herbaria material, we concluded that this collection is the first record of this species for the Brazilian Atlantic Forest. In Brazil, it had only been registered in the 
Caatinga and Cerrado phytogeographical domains (BFG, 2018). It is a significant find, since this species plays an important role in the maintenance and conservation of indigenous bees and it is widely used as an ornamental plant (Maia-Silva, Silva, Hrncir, Queiroz, \& Imperatriz-Fonseca, 2012).

Our discovery might change the interpretation of this species' ecological/morphological range, its distribution pattern and its conservation status, and therefore the present work aims to report the first record of A. blanchetii in the Atlantic Forest. Herein, we present a morphological description, photographs, comments on the geographic distribution, and assessment of the conservation status of $A$. blanchetii, as well as an identification key for the Allamanda species in the Atlantic Forest.

The collected samples were processed according to standard taxonomic techniques (Mori, Silva, Lisboa, \& COradin., 1989) and deposited into HUVA, with duplicates sent to EAC (acronyms according to Thiers, 2020).
Identification was done through morphological comparison with online exsiccates that were previouslby identified by experts (CRIA, 2016), and confirmed through the analysis of online type collections (https://plants.jstor.org/). The morphological description was based on the samples collected, using the terminology adopted by Harris and Harris (2001), and part of the corolla tube follow Moraes and Fuentes (2004). Data referring to the flowering and fruiting period were obtained from field observations. The species distribution map was prepared in the QGIS v. 1.4 software, using records with original geographical coordinates and those that were taxonomically verified by an expert. To assess conservation status, the area of occupancy (AOO) and extent of occurrence (EOO) were calculated using the Geospatial Conservation Assessment Tool GeoCAT (Geospatial Conservation Assessment Tool; Bachman et al., 2011) and following the IUCN Red List Categories and Criteria (IUCN, 2019). The main diagnostic characters have been illustrated.

\section{Identification key for the Allamanda species from the Atlantic Forest}

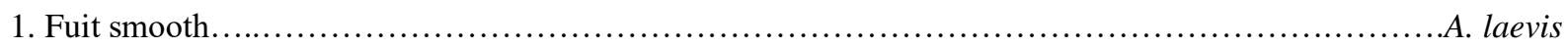

1 '. Fruit with spines.

2. Leaf blade with both surfaces pubescent.

3. Bracts pubescent; corolla purple A. blanchetii

3'. Bracts glabbrous; corolla yellow. A. polyantha

2'. Leaf blade with both surfaces glabrous or only glabrous adaxially.

4. Leaf blade with both surfaces glabrous; linear bracts A. martii

4'. Leaf blade only with the adaxial surface glabrous; lanceolate bracts.

5. Corolla fauce with scaly and ciliated hairs A. oenotherifolia

5'. Corolla fauce with silky hair .A. schottii

\section{A-F)}

Allamanda blanchetii A.DC., Prodr., 8: 319, 1844 (Figure

Type: Brazil. Bahia, Serra da Jacobina, s.d., Blanchet 2695 (holotype, G-DC!; isotypes B [destroyed, photo F neg. 1381!], BM!, G!, NY! [photo, INB!], P! [photo, INB!]).

Shrub ca. $1 \mathrm{~m}$ tall; branches subescandent, glabrous. Leaves 3 verticillate, sessile; leaf blades $4.5-11.5 \times 3.3-3.5 \mathrm{~cm}$, papyraceous, elliptic, apex acuminate, base attenuate, margins entire, both surfaces pubescent, main and secondary veins conspicuous. Flowers in bostrix terminal or axillar; linear bracts, scarious, pubescent, pedicel $0.8-1.5 \mathrm{~cm}$ long. Sepals $1.7-2 \times 0.61 \mathrm{~cm}$ long, lanceolate, with glands. Corolla funnel shaped with lower tube $2.5-3.8 \mathrm{~cm}$ long, upper tube $2.5-3.8 \mathrm{~cm}$ long lobes rounded, purple, fauce sedose, ovary with nectariferous disk deeply pentalobed. Capsule elliptic to compressed, lateraly, $4.5-6.5 \times 3.5-4 \mathrm{~cm}$, with spines. Seeds orbicular, winged, ca. $3.5 \mathrm{~cm}$ diam., thickened in the central region.

Taxonomic notes: Allamanda blanchetii is well known as it is the only species with a purple or pinkish purple corolla. It is characterized by its shrubby habit, verticillate and elliptic leaves, with both surfaces pubescent, bracts linear and pubescent, a nectariferous disk that is deeply pentalobed, a elliptic, compressed fruit with spines. It is similar to $A$. polyantha by share leaf blade with both surface pubescent but it differs from it by having pubescent bracts and a purple corolla (vs. glabrous bracts and a yellow corolla).

Distribution and conservation notes: This species is endemic to Brazil, where it is known from the Northeast (all states) and Midwest regions (Goiás), and had previously only been registered in the Caatinga, and Cerrado domains (BFG, 2018). Here, it is reported in the Atlantic Forest, where it was found on a rocky outcrop of Semideciduous Seasonal Forest in Ceará state, in brejo de altitude (Figure 2) at elevation from 730 to $780 \mathrm{~m}$. Allamanda blanchetii was defined here as Least Concern (LC) due to its EOO of $456,540,879 \mathrm{~km}^{2}$ $\mathrm{B} 1 \mathrm{a}$ (ii, iii). The populations registered in the Atllantic Forest were not found in protected area. This population was found with flowers in January.

Examined Material: Ceará, Itapipoca, Pico da Serra de Itacoatiara, 11 January 2016, fl., F.D. Santos 461 (HUVA).

Allamanda blanchetii was recorded in the Semideciduous Seasonal Forest in brejos de altitude in Ceará State, where it grows on rocky outcrops. Altitude swamps are disjunct islands of the Semideciduous Seasonal 
Forest (phytophysiognomy of the Atlantic Forest) within the semiarid region in the Northeast Brazil (Tabarelli \& Santos, 2004). These islands in the middle of the semiarid were formed by climatic variations that occurred during the
Pleistocene (Andrade-Lima, 1982), which remained in higher altitude areas, presenting unique ecological conditions for the Atlantic Forest species (Andrade-Lima, 1982).

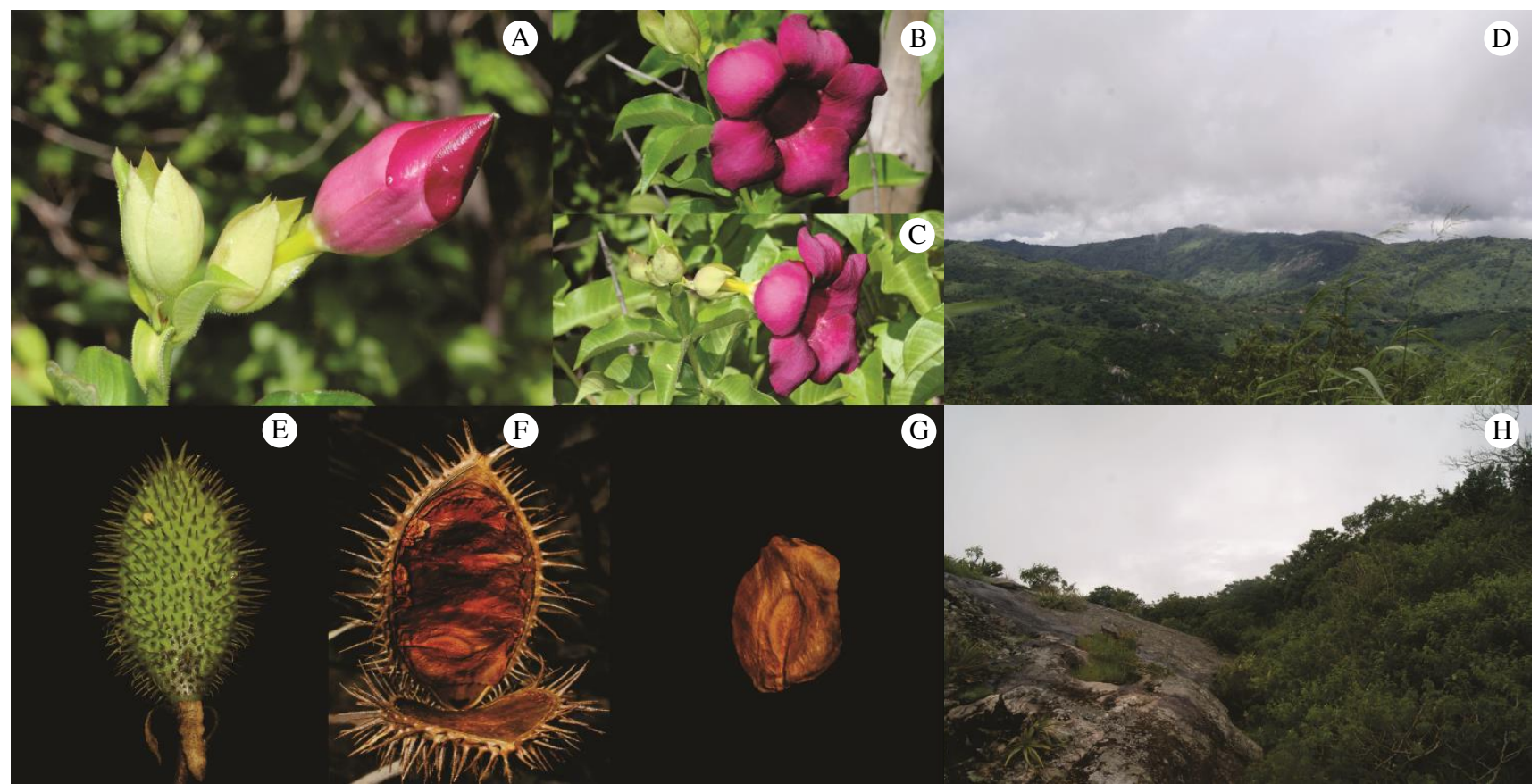

Figure 1. Allamanda blanchetii. Floral button with pubescent bracts (A). Corolla funnel shaped and purple (B and C). Capsule elliptic to compressed, immature with spines (E). Dehisced capsule exposing the seeds (F). Seeds orbicular, winged, and thickened in the central region (G). Habitat of Allamanda blanchetii (D) and Islands of vegetation on rocky outcrops in the Massif of Uruburetama (H).

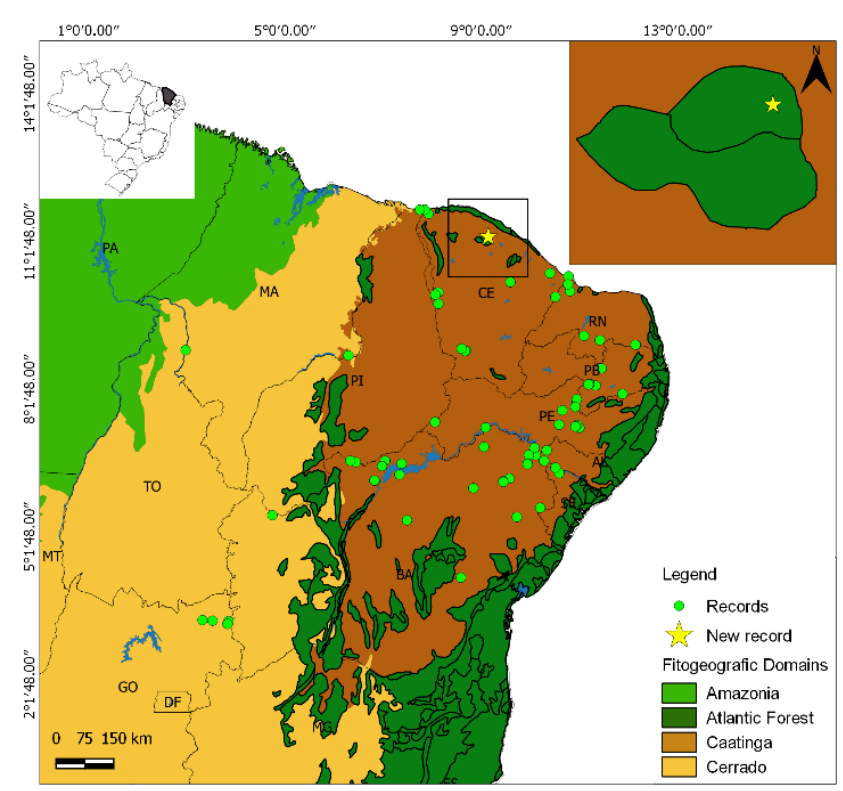

Figure 2. Geographic distribution of Allamanda blanchetii.

Allamanda blanchetii had been registered only for caatinga and cerrado vegetation. However, our discovery revealed that it also occurs in vegetation on rocky outcrop in Semideciduous Seasonal Forest. Among the species of this genus from Atlantic Forest, A. laevis and A. oenotherifolia were the only ones recorded in vegetation on rocky outcrops. With this discovery, it is possible to understand the ecological relationships between species in the Atlantic Forest. Regarding its conservation, it is important to note that this new record expands the occurrence area of A. blanchetii, which is important for future reassessments of their conservation status by obtaining data on their local populations and the conservation status of their habitats. This new record reinforces the need to expand floristic studies in the Atlantic Forest to increase understanding about the occurrence area of this species, and calls attention to the importance of defining public policies that can prevent the local extinction of this species in Ceará.

\section{Acknowledgments}

We are grateful to the Coordenação de Aperfeiçoamento de Pessoal de Nível Superior (CAPES) for granting a scholarship to the first author; to Universidade Federal Rural de Pernambuco for financial support for the research; to the curators of the herbaria HUVA and EAC; and to Hannah Doerrier for English review.

\section{References}

Andrade-lima, D. (1982). Present day forest refuges in Northeastern Brazil. Pp. 245-254, in: Prance, G.T. (ed.). Biological Diversification in the Tropics. Columbia University Press, New York

Bachman, S., Moatc, J., Hill, A. W., De la Torre, J., \& Scott, B. (2011). 
Supporting Red List threat assessments with GeoCAT: Geospatial conservation assessment tool. ZooKeys 150: 117-126. doi: 10.3897/zookeys.150.2109

BFG - The Brazil Flora Group (2018). Brazilian Flora 2020: innovation and collaboration to meet Target 1 of the Global Strategy for Plant Conservation (GSPC). Rodriguésia 69(4): 1513-1527. doi: 10.1590/21757860201869402

CNCFlora (2021). Base de Dados do Centro Nacional de Conservação da Flora.

CRIA (2016). Geoloc.

Harris, J., \& Harris, M. (2001). Plant identification terminology: an illustrated glossary (2 ed.) Utah: Spring Lake Publishing.

IUCN (2019). IUCN red list categories and criteria, version 3.1. Ed. 2. Gland, Switzerland and Cambridge, U.K.: IUCN.

Maia-Silva, C., Silva, C. I., Hrncir, M., Queiroz, R. T., \& Imperatriz-Fonseca, V. L. (2012). Guia de plantas visitadas por abelhas na Caatinga. 1. ed. Fortaleza, CE: Editora Fundação Brasil Cidadão.

Morales, J. F., \& A. Fuentes (2004) Estudios en las Apocynaceae Neotropicales VIII: nuevas especies de Mandevilla para Peru y Bolivia, con notas sobre la morfologia floral en corolas infundibuliformes. Candollea 59(1): 167174 .

Mori, A. S., Silva, L. A. M., Lisboa, G., \& Coradin, L. (1989). Manual de Manejo do Herbário Fanerogâmico (2 ed.) Centro de Pesquisas do Cacau, Itabuna.

Sakane, M. (1981). Revisão do Gênero Allamanda L. (Apocynaceae) no Brasil. 107p. (Dissertação de Mestrado). Instituto de Biologia. Universidade Estadual de Campinas. Campinas.

Sakane, M., \& Shepehed, G. J. (1986). Revisão do gênero Allamanda L. (Apocynaceae). Revista Brasileira de Botânica 9(2): 125-149.

Tabarelli, M., \& Santos, A. M. M. (2004). Uma breve descrição sobre a história natural dos brejos nordestinos. 99-110. In: Pôrto, K.C., Cabral, J.J.P., Tabarelli, M., eds. Brejos de altitude em Pernambuco e Paraíba: história natural, ecologia e conservação. Brasília: Ministério do Meio Ambiente.

Thiers, B. (2020) [continuously updatebd] Index herbariorum: a global directory of public herbaria and associated staff. New York Botanical Garden's Virtual Herbarium.

License: Creative Commons CC BY NC 4.0 